\title{
Who Invented the Bronze Drum? Nationalism, Politics, and a Sino-Vietnamese Archaeological Debate of the 1970s and 1980s
}

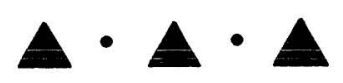

XIAORONG HAN

EVER SINCE THE BIRTH OF MODERN ARCHAEOLOGY in the nineteenth century, nationalism and politics have been important factors in its development, and as such, archaeologists in various parts of the world have been actively involved in the construction of ethnic and/or national origins and identities, the corroboration of national myths, the disputes over territories and cultural inventions, and so on (Diaz-Andreu and Champion 1996; Hudson 1999; Kohl and Fawcett 1995; Meskell 1998; Pai 2000; Silberman 1989; Trigger 1984). Although it is difficult to find a single country in which archaeology is completely free from the influence of nationalism and politics, it is understandable to find that archaeologists operating in authoritarian systems generally have a stronger tendency to develop a close relationship with the nation-state and involve themselves in politics because of a lack of academic freedom and independent sources of financial support. Nazi Germany, early twentieth-century Japan, and pre-World War II Soviet Union are extreme examples of the politicization of archaeology (Arnold and Hassman 1995; Hudson 1999:35, 44; Shnirelman 1996; Trigger 1989:178179; Wiwjorra 1996). In post-war Asia, archaeologists in China and Viet Nam were actively engaged in the development of a new wave of nationalist archaeology under the encouragement and sponsorship of the state (Glover 1999; Tong 1995).

This paper intends to study the nationalist archaeology of China and Viet Nam in the 1970s and 1980s. Its focus is on the Sino-Vietnamese archaeological debate on the geographic and ethnic origins of the bronze drum. Based on a review of the major works on the bronze drum published in Viet Nam and China since the 1950s, I argue that nationalism and international politics had such strong bearings on the studies of the bronze drum in both countries in the 1970s and 1980s that an individual archaeologist's views on certain issues were largely determined by his nationality. The chief concern here is not to prove which side has the correct interpretation, rather, it seeks to explain the origins of the debate, while exploring why no scholars expressed different views from those of their compatriots. 
My presentation will open with a brief history of bronze drum studies. The focus of the paper will be on the three most controversial issues regarding the origins of the bronze drum: classification, dating, and interpretations of the decorations. The paper will conclude with some general observations on nationalism and archaeology in Viet Nam and China.

\section{HISTORY OF BRONZE DRUM STUDIES}

Bronze drums are one of the most important archaeological artifacts to be found in southern China and Southeast Asia. Their use by many ethnic groups in the area has lasted from prehistoric times to the present. Though bronze drums have been found in a wide area from the Yangtze River area in China in the north to the Kai Islands of Indonesia in the east and south and the Bengal Bay in the west, northern Viet Nam and southwestern China (especially Yunnan Province and the Guangxi Zhuang Autonomous Region) are the two areas where the majority of bronze drums have been discovered (Jiang Tingyu 1999:37-40; Phạm Minh Huyền et al. 1987:34-38; Spennemann 1987:71; Yoshikai 1998:199, 213). According to a 1980 report, China had collected about 1460 bronze drums. They were kept in the provinces and cities of Guangxi, Guangdong, Shanghai, Yunnan, Guizhou, Beijing, Sichuan, Hunan, Shandong, Hubei, Zhejiang, Liaoning, and other places (ZGTY 1988:8). The same number was reported in a 1995 news article, even though several more bronze drums were discovered in the 1980 s and 1990s (Jiang 1999:22-25; Xinhua News Agency 1995). The total number of bronze drums discovered in Viet Nam reached about 360 in the 1980s, among which, about 140 were Đông Sơn drums (Nguyễn Duy Hinh 1987:4-5; Phạm Huy Thòng 1990:265). Due to more Đông Sơn drums being excavated in Viet Nam in the 1990s, Vietnamese scholars have placed the total number of Đông Sơn drums discovered in Viet Nam at around 150 or 190 (cf. Đinh Bá Hoà 1998; Jiang 1999: 25; Phạm Dức Mạnh 1997).

The earliest historical records about bronze drums appeared in the Shi Ben, a Chinese book written in the third century B.C. or earlier. Although the book is no longer extant, a small portion of it appears in another classic, the Tongdian, by Du You (Xu Songshi 1977:7-8). The Hou Han Shu, a Chinese chronicle of the later Han period compiled in the fifth century A.D., describes how the Han dynasty general Ma Yuan collected bronze drums from northern Viet Nam or Guangxi (Qiu Zhonglun 1982:159-162) to be melted down and recast into bronze horses. From that point on, many official and unofficial Chinese historical records contain references to bronze drums. In Viet Nam, two fourteenth-century literary works written in Chinese by Vietnamese scholars, the Việt Điện U Linh and the Linh Nam Chích Quái, record many legends about bronze drums. Later works such as the Đại Viẹt Sủ Ký Toàn Thu, a historical work written in the fifteenth century, and the Đại Nam Nhất Thống Chí, a book about the historical geography of Viet Nam compiled in the late nineteenth century, also contain records pertaining to bronze drums (Nguyễn Duy Hinh 1974:18-20).

Modern archaeological research on the bronze drum did not begin until the late nineteenth century, however, after the arrival of Westerners in the region. Almost all the important archaeological works on the bronze drum prior to the 1950 s were written by Western scholars. Notable works from this period are F. 
Hirth's Alte bronzepauken aus Ostasien (1891), A. B. Meyer and W. Foy's Bronzepauken aus Südostasien (1897), Franz Heger's Alte Metalltrommeln aus Südostasien (1902), and Bernhard Karlgren's "The date of the early Dong-son Culture" (1942) (cf. Glover 1999:595-596; Loofs-Wissowa 1983:1-3; Phạm Minh Huyền et al. 1987:12-14, 306-309; ZGTY 1988:10-12). Due to the sociopolitical circumstances, few Vietnamese scholars were able to engage in research on the bronze drum during the colonial period. In China, a monograph entitled Tonggu kaolüe, written by Zheng Shixu, was published in Shanghai in 1936. Although some famous Chinese scholars, such as the historians Xu Songshi and Luo Xianglin, also showed interest in the bronze drum, no other significant Chinese works on bronze drums were produced during this period.

After the establishment of the PRC in 1949 and the division of Viet Nam in 1954, Vietnamese and Chinese scholars began to catch up with their Western counterparts in bronze drum research. In the 1950s and 1960s, some excavation reports and general studies on bronze drums were published. However, on the whole, the bronze drum did not attract much serious academic attention in either country. It was not until the mid-1970s that many important articles and books on the bronze drum began to be published in both countries. This started with the publication in Viet Nam of the two special issues of Khảo Cổ Học on the bronze drum in 1974 and the publication of two important articles on the bronze drum in China in the same year (Feng 1974; Hong 1974). The late 1970s and early 1980s saw the publication of many more books and articles on the topic in both China and Viet Nam, thus engendering heated debates between Vietnamese and Chinese scholars (Chư 1982; Jiang 1982; Li Weiqing 1979; Li and Xi 1983; Nguyễn Duy Hinh 1979, 1982a, 1982b; Phạm Huy Thòng 1982; Shi 1983; Tong 1983; Trần Quốc Vưởng 1982; Wang Ningsheng 1978). In March 1980, the first Chinese symposium on the bronze drum was held in Nanning, southern China, followed immediately by the formation of the Chinese Association for Ancient Bronze Drum Studies. The second symposium on the bronze drum held in Kunming in late 1983 (Wenwu bianji weiyuanhui 1990:376, 380) was followed by four international conferences on the bronze drum and bronze culture of southern China and Southeast Asia, held in 1988, 1991, 1996, and 1998, respectively (Jiang 1999:285-286). In 1987, Vietnamese scholars summed up their views in the book Trống Đông Sơn (Phạm Minh Huyền et al. 1987). The following year, the Chinese scholars (ZGTY) also compiled a conclusive monograph entitled Zhongguo Gudai Tonggu (ZGTY 1988). In November 1996, Vietnamese and Chinese archaeologists met at the Third International Symposium on the Bronze Drum and Bronze Culture of South China and Southeast Asia for the first time in about two decades (Jiang 1999:286). The publication of the abovementioned two books and this symposium actually brought the protracted controversy to a halt. Since then, the debate has abated.

The timing of this Vietnamese and Chinese research and debate on the bronze drum reveals much about its political implications. The boom in bronze drum research started in the mid 1970 s when Sino-Vietnamese friendship was about to turn sour, and it ended in the late 1980s and early 1990s when the two countries were ready to seek a solution for their problematic relations. The political influence on research is reflected not only in the number of publications produced, but also in the issues that Vietnamese and Chinese archaeologists chose to address. 
While due attention was paid to the classification, dating, functions, molding techniques, and other issues relating to the bronze drum, the debate was mainly centered on the issue of the geographic and ethnic origins of the bronze drum. Where and when the first bronze drum was made and who made it were the core issues in the controversy between Chinese and Vietnamese scholars: Vietnamese scholars unanimously claimed that the bronze drum was invented in the Red and Black River valleys in northern Viet Nam by the Lạc Việt, the remote ancestors of the Vietnamese people, and then spread to other parts of Southeast Asia and southern China (Phạm Minh Huyền et al. 1987:223-225). Meanwhile, Chinese archaeologists on the other hand, declared that the real inventor of the bronze drum was an ancient ethnic group inhabiting central Yunnan in southwestern China, and that the technique was then adopted by other ethnic groups living in the surrounding areas, including the Lac Việt in the Red River delta (ZGTY $1988: 26,126-129)$. Their respective theories about the origin of the bronze drum in turn influenced their understanding of other important aspects of the bronze drum, such as its classification, dating, and decoration.

\section{CLASSIFICATION AND DATING}

The Austrian archaeologist, Franz Heger, conceptualized the best-known classification of the bronze drum in 1902 with his Alte Metalltrommeln aus Südostasien. He collected 22 bronze drums and the records or photographs of another 143, which he divided into four types (I, II, III, IV) and three transitory types (I-II, II-IV, I-IV) based on their form, distribution, decoration, and chemical composition. Figure 1 illustrates the four different types of bronze drums in Heger's 1902 classification. Heger believed that Type I, which was later called the Đông Sơn drum by Vietnamese scholars, was the earliest (Phạm Minh Huyền et al. 1987:19-21; ZGTY 1988:10-11). Some other classifications were proposed before Heger, including a Chinese classification based on the size of the bronze drums (large, medium, and small), another Chinese classification based on the time period of the bronze drums (Han Dynasty bronze drum, Tang Dynasty bronze drum, and so on), and a six-type classification by Meyer and Foy (ZGTY 1988:29-30), but none of these was as widely adopted as Heger's.

Did Heger's classification stand the test of time and the excavation of many more bronze drums? Vietnamese scholars thought that the general framework of Heger's classification was still valid, and that it could be modified or expanded, but should not be replaced. They therefore chose to leave Heger's general framework intact and to concentrate on the details, with the aim of further supporting Heger's classification with new evidence discovered after 1902. With many more bronze drums in hand, Vietnamese scholars began to divide each of Heger's types into several subtypes. Their efforts were chiefly focused on Heger's Type I, namely, the Đông Sơn drum, believed to be the earliest of the various types of bronze drums. For example, in 1963, Lê Văn Lan and others proposed to subdivide Heger's Type I according to the proportion between the diameter of the face and the height of the drum (Phạm Minh Huyền et al. 1987:21-22). At least four new schemes were proposed in 1974: Trần Mạnh Phú subdivided Heger's Type I into four subtypes, as did Lưu Trân Tiêu and Nguyễn Minh Chương (Lưu and Nguyễn 1974:117-121; Trần Mạnh Phú 1974:83-94). Chử Văn Tần proposed two subtypes with five transitory types (Chử 1974:106-116). Diệp Đinh Hoa 

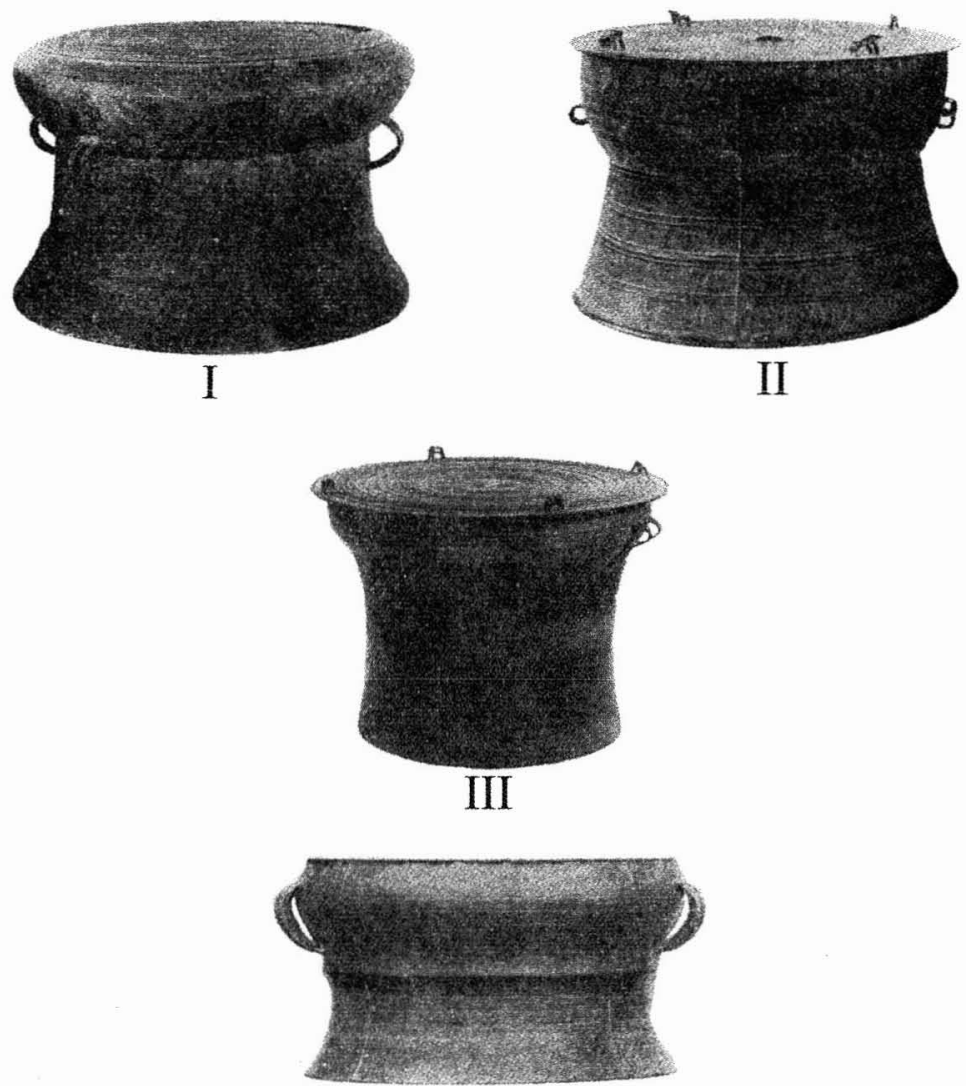

IV

Fig. 1. Heger's four types of bronze drum (Matsumoto 1965:81).

and Phạm Minh Huyền suggested seven subtypes (Diệp and Phạm 1974:126134). In the following year, two additional classification schemes were proposed: Nguyễn Văn Huyên and Hoang Vinh subdivided Heger's Type I into three subtypes (Nguyễn and Hoàng 1975), and Phạm Văn Kỉnh and Quang Văn Cây suggested seven subtypes belonging to four consecutive stages (Phạm Minh Huyền et al. 1987:21-22). Among all the new classification schemes, however, the most complicated was the one proposed by Phạm Minh Huyền, Nguyễn Văn Huyên, and Trinh Sinh, who divided Heger's Type I into six subtypes with 24 styles (Phạm Minh Huyền et al. 1987:23-34, 120-123).

Vietnamese scholars paid much more attention to Heger's Type I drum than to the other types of bronze drum that Heger had identified. They saw these other types as later in date and less related to the antiquity of the Vietnamese people. For example, Heger's Type II was mostly found in southern China and among the Mường minority of Viet Nam; Type III existed in Burma and southern China but not in Viet Nam; Type IV was believed to exist in southern China only (Pham Huy Thòng 1974:9-11). It was reported in the 1980s that only 14 Type III drums and 6 Type IV drums had been found in Viet Nam (Nguyễn Duy Hinh 1987:4). 
Table i. Major Classification Schemes Proposed by Chinese Scholars

\begin{tabular}{|c|c|c|c|c|c|c|c|c|c|}
\hline AUTHOR & \multicolumn{8}{|c|}{ CLASSIFICATION } & YEAR \\
\hline Heger & & \multicolumn{3}{|c|}{ I } & \multicolumn{2}{|c|}{ II } & III & IV & 1902 \\
\hline Wen You & & \multicolumn{3}{|c|}{ II (western) } & \multicolumn{2}{|c|}{ I (eastern) } & & III & 1957 \\
\hline Yunnan Museum & & I & \multicolumn{2}{|c|}{ II } & & & III & IV & 1959 \\
\hline Huang Zengqing & & \multicolumn{3}{|c|}{ II } & III & I & & IV & 1964 \\
\hline Hong Sheng & & \multicolumn{3}{|c|}{ III } & II & I & & IV & 1974 \\
\hline Wang Ningsheng & A & B & \multicolumn{2}{|c|}{ C } & \multicolumn{2}{|c|}{$\mathrm{D}$} & $\mathrm{F}$ & E & 1978 \\
\hline Li Weiqing & $\mathrm{I}: \mathrm{a}$ & $\mathrm{I}: \mathrm{b}$ & \multicolumn{2}{|c|}{$\mathrm{I}: \mathrm{C}$} & II : a & II $: b$ & III : a & III $: b$ & 1979 \\
\hline $\begin{array}{c}\text { Zhang Shiquan } \\
\text { Shi Zhongjian } \\
\text { ZGTY }\end{array}$ & 1 & 2 & 3 & 4 & 6 & 7 & 8 & 5 & $\begin{array}{l}1982 \\
1983 \\
1988\end{array}$ \\
\hline
\end{tabular}

Note: Based on Li Weiqing 1979; Phạm Min Huyền et al. 1987:22; Shi Zhongjian 1983; Wang Ningsheng 1989:22; ZGTY 1988.

The attitude of Chinese archaeologists toward Heger's classification sharply contrasts with that of Vietnamese scholars. They believed that Heger's classification was so outdated that it necessitated major revisions (Hong 1974; Huang 1964; Li Weiqing 1979; Shi 1983; Wang Ningsheng 1978; Wen 1957). After the break-up of the bilateral relations between China and Viet Nam, Chinese scholars began to openly criticize Vietnamese scholars for what they interpreted as blind and unacademic adherence to Heger's old classification. As one Chinese book put it, Heger could be forgiven for asserting that his Type I drum was the earliest, because he did not have enough evidence at that time, but Vietnamese scholars could not be forgiven because despite having so much more information than Heger, they still persisted in their refusal to pay due attention to this new evidence (ZGTY 1982:6-7, 1988:12).

From the 1950 s to the 1980 s, Chinese scholars made about ten new classification schemes, which are summarized in Table 1. From the 1950 s to the mid 1970s, Chinese scholars endeavored to reverse the order of Heger's first three types by categorizing his Type II as the earliest through the argument that Heger's Type I had in fact developed from his Type II. Three out of four classifications made by Chinese scholars during that period did precisely that (Hong 1974; Huang 1964; Wen 1957). While the scheme conceived by the Yunnan Provincial Museum continued to support Heger's order, it chose to divide Heger's Type I into two different types ( $\mathrm{Li}$ Weiqing 1979:66-78). These modifications of Heger's classification naturally led to much suspicion from the Vietnamese scholars because they were aware of two facts: China did not have many Heger's Type I bronze drums at that time, and the great majority of Heger's Type II drums had been discovered in Guangxi in southern China.

By the mid to late 1970s, China had discovered many bronze drums believed to belong to Heger's Type I, almost all of which were found in Yunnan Province. In 1987 a Chinese scholar put the total number of Type I bronze drums dis- 
covered in Yunnan at 55 (Tong 1986 [1990]: 196-197). Moreover, after the excavation of Wanjiaba in Yunnan Province in 1975-1976, Chinese archaeologists believed that they had found the predecessor of Heger's Type I bronze drum, which they called a Wanjiaba bronze drum. By 1990, Chinese archaeologists had identified 29 Wanjiaba bronze drums, of which 26 were found in Yunnan, one in Viet Nam, and two in Thailand (Li and Huang 1991a [1980], $1991 b$ [1990]). As a result of the new discovery, Chinese scholars began to discard the schemes they made in the previous period and returned to Heger's classification. In this reversion to Heger's classification however, one important modification was made: the newly found Wanjiaba drums were added to Heger's classification and were declared as the earliest type. Wang Ningsheng, Li Weiqing, and Shi Zhongjian represented this new revisionist school (Li 1979; Shi 1983; Wang 1978). Despite supporting the earlier Chinese view that southern China had yielded the earliest bronze drum, their works differed greatly from most of the previous Chinese classifications in that they accepted Yunnan, instead of Guangxi, as the place of origin of the bronze drum within southern China.

This indicated some differences between the Chinese scholars in Guangxi and their colleagues in Yunnan. As mentioned above, among the four major classifications made by Chinese scholars between the early 1950s and the mid 1970s, only the scheme by the Yunnan Provincial Museum refused to recognize Heger's Type II, which was found mostly in Guangxi, as the earliest bronze drum. Part of the reason for the difference is that in the late 1950s, quite a few bronze drums belonging to Heger's Type I were excavated at Shizhaishan in Yunnan. It was probably not a coincidence that two of the three scholars who claimed the Guangxi origin of the bronze drum between the 1950s and 1970s, Huang Zengqing and Hong Sheng, were from Guangxi, while the other, Wen You, hailed from Beijing. Interestingly, this same pattern was discernable in the Yunnan school as two of the three scholars who claimed the Yunnan origin of the bronze drum in the 1970s and 1980s, Wang Ningsheng and Li Weiqing, worked in Yunnan, whereas the other, Shi Zhongjian, came from the neutral ground of Beijing. Shi's classification method was based on a scheme that was previously proposed by Zhang Shiquan who was working in Guangxi at that time (Zhang 1982:95-107). It was reported in 1982 that a majority of Chinese archaeologists had agreed that the bronze drum originated in Yunnan (Shi 1982:203). The implication behind this was the existence of a minority that did not agree with the Yunnan school. The debate with Vietnamese scholars had probably prevented this minority among the Chinese scholars from expressing their views. At the second symposium on bronze drums held in 1983, two different views on the origin of the bronze drums were proposed. One group of scholars claimed Yunnan as the sole place of origin of the bronze drum, whereas another group of scholars argued that the bronze drum had two places of origins: Guangxi and Yunnan (ZGTY 1986:2-3). However, in the proceedings published after the symposium, papers supporting the second view were not included. At about the same time, there was a third view that placed bronze drums' origins in the vast area covering the four provinces of Sichuan, Yunnan, Guizhou, and Guangxi in southern China (quoted in Li Weiqing 1991:481); this view, however, failed to gain popularity. Yet, these differences among the Chinese scholars did nothing to stop the formal announcement in 1995 that Chinese archaeologists had all agreed that the Wanjiaba type bronze drum was the earliest in the world and that Chuxiong prefecture in Yunnan, 
where Wanjiaba is located, was the birthplace of the bronze drum (Xinhua News Agency 1995).

It is interesting to note that a key means of bolstering their claims surrounding the origins of the bronze drum was to name each type of bronze drum after the name of the place in their own country where it was found. Just as Vietnamese scholars preferred to name the bronze drum after Vietnamese places (for example, the Đông Sơn drum, or Heger's Type I drum, named after the village where about twenty bronze drums were excavated between 1924 and 1932), Chinese scholars also liked to use Chinese place names in their classifications. For instance, Shi Zhongjian (Shi 1983) chose the following Chinese place names to designate his eight types of bronze drum: (1) Wanjiaba (Yunnan); (2) Shizhaishan (Yunnan); (3) Lengshuichong (Guangxi); (4) Zunyi (Guizhou); (5) Majiang (Guizhou); (6) Beiliu (Guangxi); (7) Lingshan (Guangxi); (8) Ximeng (Yunnan). Hence, the Vietnamese scholars label Heger's Type I drum as the Đông Sơn drum, while Chinese scholars label it as either the Shizhaishan, Lengshuichong, or Zunyi drum. A similar practice is adopted by archaeologists in southeastern Europe, where "modern geo-political boundaries acted as unstated criteria for classifying artefactual material. If an artifact was found on one side of a modern frontier then it belonged to one 'culture'; if found on the other side then it belonged to another 'culture.' These different cultures were identified by different names ..." (Kaiser 1995: 108-109).

Though some foreign scholars did accept the new classifications of Wang Ningsheng, Li Weiqing, and Shi Zhongjian (Jiang 1999:32-33; Peng 1991; Spennemann 1987:71), these schemes as a whole, failed to win the approval of any Vietnamese scholar. Vietnamese scholars claimed that the new classifications made by Chinese archaeologists were groundless. They argued that besides the fact that China had few of Heger's Type I drums before the excavation at Shizhaishan, Chinese scholars had reversed the order of Heger's first three types before the mid 1970s, because they believed that the bronze culture in the south could not have developed without the influence of Han Chinese culture from the north. Heger's Type II, Vietnamese scholars noted, had something which Chinese scholars were looking for: decorations similar to those found in the Central Plains of China. These classifications, Vietnamese scholars argued, just like the widespread belief in premodern China that the bronze drum had been invented by Ma Yuan, the Han general who crushed the Trung sisters' rebellion in Viet Nam in A.D. 40, or Zhuge Liang, the famous prime minister of the state of Shu during the Three Kingdoms period (A.D. 220-265), ${ }^{1}$ reflected the mentality of Han Chinese chauvinism. To Vietnamese scholars, Chinese influences were not indications of an earlier date, but precisely the opposite (Nguyễn Duy Hinh 1979:17-19).

The more recent Chinese classifications, which returned to Heger's plan but added the Wanjiaba drums to the classification as the earliest type, were based partially on the idea that the form and decoration of the Wanjiaba drums were very simple, and the premise that the simpler the form and decoration, the more archaic the drum would be. Vietnamese scholars on the other hand believed that this was another misinterpretation. The three principles used by Chinese scholars in their classification, namely, that "the face of the drum growing bigger and bigger, the body of the drum decreasing from three to two parts, and the decorations becoming more and more complex," were considered to be oversimplifications by Vietnamese scholars. They argued that the simple form and decorations could 


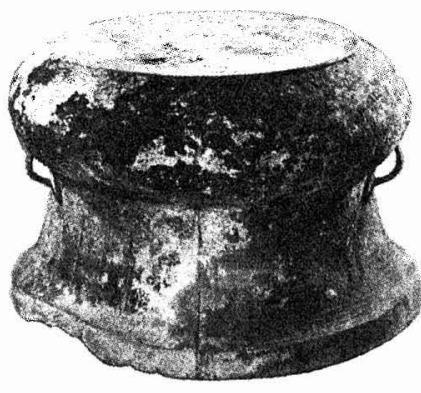

a

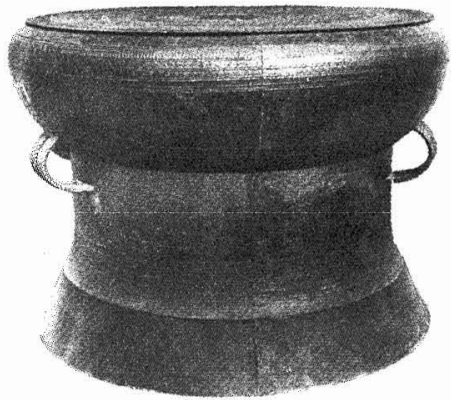

C

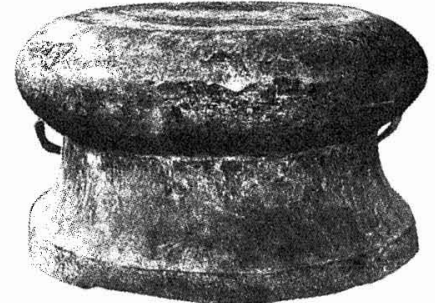

b

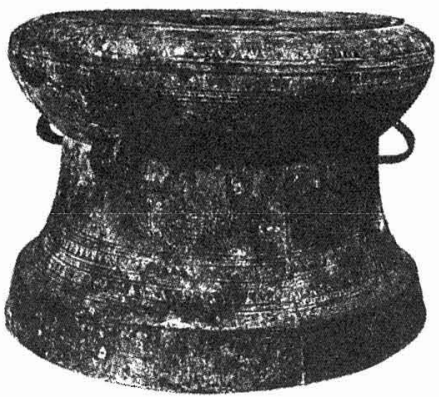

d

Fig. 2. A comparison of the controversial bronze drums discovered in Viet Nam and China (the Thuong Nong drum is a Wanjiaba-style bronze drum discovered in Viet Nam, and the Ngoc Lũ drum is one of the best-known Đông Sơn drums). a: Wanjiaba drum (China) (ZGTY 1988: Pl. 9); b: Thuong Nong drum (Viet Nam) (Phạm Huy Thòng 1990:210); c: Ngọc Lũ drum (Viet Nam) (Phạm Huy Thòng 1990: 4); d: Shizhaishan drum (China) (ZGTY 1988: Pl. 14).

also be indications of decline, thereby implying that the Wanjiaba drum was not the earliest bronze drum, but the latest (Chư 1982:33; Nguyễn Duy Hinh 1979:21). According to Phạm Huy Thòng, drums of the Wanjiaba type were found in Viet Nam as early as the 1930s and had long since been judged to be coarse, but late (Pham 1990:269). Thus, in the most complicated Vietnamese classification scheme proposed in 1987 (Phạm Minh Huyền et al. 1987), the Wanjiaba drum was listed as the fourth subtype of the Đông Sơn drum (Heger's Type I). The Thuong Nong drum, a Wanjiaba-style bronze drum found in Viet Nam in the 1980s, was therefore labeled as the same subtype. Figure 2 offers a comparison of the controversial bronze drums discovered in Viet Nam and China.

The aim of all of these classifications was to determine the relative dating of the bronze drums. The central issue in this dispute lies with the question of whether the earliest bronze drums were made in northern Viet Nam or southern China? To date, scholars in the two countries have not found common ground on this issue. The debate mainly revolves around the first two types of Heger's classification, which are directly linked to the issue of the origins of the bronze drum. Since relative dating proved unconvincing, Chinese and Vietnamese scholars sought to attempt a means at absolute dating. However, this proved to be as controversial as relative dating. 
Western scholars had dated Heger's Type I drums to the first century A.D., or the third, fourth, or fifth century B.C. (Loofs-Wissowa 1983:2-3). Both Vietnamese and Chinese scholars agreed that the earliest drums could be dated to before the fifth century B.C., but again they could not agree with each other as to where the earliest drum was made. The Vietnamese scholar Vũ Thắng proclaimed in 1974 that a bronze fragment discovered in northern Viet Nam originally came from a bronze drum or a predecessor of the bronze drum, and he dated the fragment from the thirteenth to tenth centuries B.C. (Vũ 1974:69-70). In addition, he further dated a bronze drum discovered in northern Viet Nam to the same period. This is the earliest absolute dating so far proclaimed for any bronze drum. However, this dating later led to much criticism from Chinese scholars, who held the method of dating as unscientific (Tong 1983 [1990]: 168-169). The dating of the drum was based on the motifs of rings and parallel lines, which are believed to be similar to those found on ceramics of that period. Moreover, the bronze fragment is too small, and it is uncertain whether it is a part of a bronze drum (Wang Ningsheng 1989:85). Apparently, Vietnamese scholars later discarded this dating scheme, as it was not included in Trống Đông Sơn, the conclusive volume compiled by Phạm Minh Huyền and others and published in 1987.

Other Vietnamese scholars believed that the earliest Đông Sơn drum can be dated alternately to the seventh century B.C. (Chử 1974; Nguyễn Văn Huyên 1974); or the eighth century B.C. (Diệp and Phạm 1974); or sometime before the seventh century B.C. (Lưu and Nguyêิ㇒n 1974). Vietnamese scholars later admitted that it was difficult to reach an exact date for the Đông Sơn drum because many drums were discovered accidentally, and as such, the sites were not well protected. Furthermore, it is very difficult to find any biological materials that are directly related to the drum to get an absolute date (Phạm Minh Huyền et al. $1987: 216-217)$.

The earliest ${ }^{14} \mathrm{C}$ date established for a bronze drum excavated in China by Chinese scholars is $2640 \pm 90$ before 1950, or $690 \pm 90$ B.C. (ZGTY 1988:110). This drum was discovered in Wanjiaba and the dating was based on the materials that coexisted with the drum in the tombs. Chinese scholars claimed that this is the earliest credible ${ }^{14} \mathrm{C}$ date for any bronze drum. They argued that the Wanjiaba type bronze drums were mostly made between the seventh and fifth centuries B.C., that the Shizhaishan (Heger's Type I or the Đông Sơn drum) type was popular between the sixth century B.C. and the first century A.D., and that the latter was a more developed form of the former (Wang Dadao 1990:536, 540).

However, according to Vietnamese scholars, the Chinese dating is erroneous. In a bid to prove their point, Vietnamese archaeologists conducted an experiment on a piece of wood obtained from an excavated coffin and subsequently found that the margin of error for such dating could be as much as 235 years (Chư 1982:30). They believed that the Chinese archaeologists deliberately chose the earlier date in order to support their claim that the bronze drum originated in southern China. According to Vietnamese scholars, the dating of bronze drums should not be based solely on ${ }^{14} \mathrm{C}$ statistics, instead, other factors should also be taken into consideration. They even went so far as to set an example for Chinese scholars. A bronze drum was found in an ancient tomb in northern Viet Nam. ${ }^{14} \mathrm{C}$ dating indicated that the tomb was from $2480 \pm 100$ years before the present, or around 530 B.C. However, based on its style, it was decided that the drum 
could only be dated to the third or fourth centuries B.C. (Chư 1982:32). To date, scholars from the two countries have failed to reach common ground regarding absolute dating, just as they have not achieved a consensus on classification or relative dating.

\section{INTERPRETATION OF THE DECORATIONS}

The decoration of the bronze drum is another major field of controversy between Vietnamese and Chinese scholars. Decorations on the bronze drum have been classified into three categories: realistic images, geometric patterns, and threedimensional figurines, and these are in turn used to determine both dating and the ethnic affiliations of the bronze drum. It is believed that the decorations reflect the social and spiritual life of the people who invented and used the drum. The most popular motifs on the early bronze drums (Heger's first two types and the Wanjiaba type) include various species of birds and other animals, as well as boats, shining entities, and geometrical lines.

A flying bird with a long beak and long feet appeared very frequently on the early drums, and a good deal of scholarly attention was devoted toward determining what kind of bird was depicted. Figure 3 includes some forms of this bird. The Vietnamese historian Đào Duy Anh believed that it was the legendary "Lac Bird," the symbol of the ancient Viet people (Đào Tử Khải 1974:27). Đào Tử Khả, however, argued that the bird was not a Lac bird because the Lac bird was a magpie or some other species whose appearance was rather different from that of the bird on the bronze drum. According to Đào Tử Khải, the bird was instead an
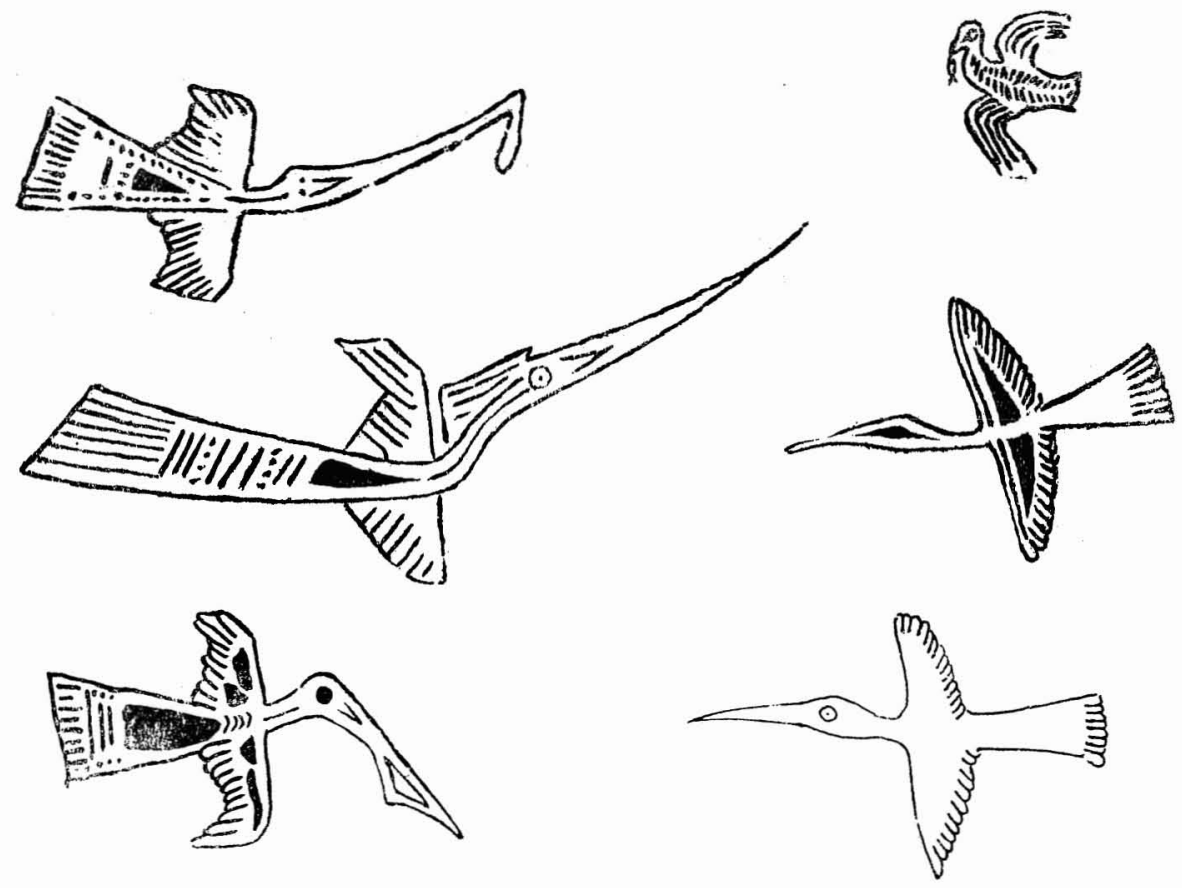

Fig. 3. Flying birds on bronze drums (ZGTY 1988:57). 
egret (Đào 1974:27). Still other scholars argued that the Lac bird and the egret are the same (Vũ Thế Long 1974:9). Moreover, it was further argued that the ancient Viet people regarded the egret as the symbol of the laborious peasants because the bird was believed to be diligent. As one Vietnamese scholar put it,

We believe that since the bronze drum is a product of Viet Nam made by the Viet people, it should reflect something real in the Vietnamese landscape. The flying bird on bronze drums should be something that the Viet people were very familiar with, and it should have a Vietnamese name. We believe that our interpretation of the bird with its long beak and long feet on bronze drums as an egret is in conformity with the reality of Vietnamese history and culture (Đào Tử Khải 1974:28-29).

On the other end of the spectrum, although most Chinese scholars believe the bird to be an egret, some Chinese archaeologists argue that the flying bird is either a crane or a hornbill (Yi 1988). Moreover, Chinese scholars who support the egret interpretation do not agree that the egret is a symbol of the ancient Vietnamese peasants or the Vietnamese nation. Rather, the bird motif is seen more as the end result of Han Chinese cultural influence. They argued that the egret was considered to be the spirit of the drum in the Central Plains of China, an idea which spread first to the Chu area in southern China, before it was adopted by other ethnic groups living to the south of Chu. According to the Chinese Association of Ancient Bronze Drum Studies,

The flying egret is the major motif on Shizhaishan drums. There is a long tradition of decorating drums with the motif of egrets in the Central Plains. The feather drums excavated from the Chu tombs in Xinyang, Henan and Jiangling, Hubei and the Zenghouyi tomb in Suixian, Hubei are all decorated with the motif of the egret ... there is clear evidence to support the idea that the motif of the flying egret on the Shizhaishan drums originated in the Chu area (ZGTY 1988:233).

In addition to the bird motifs, there are also small three-dimensioned animals on the face of some drums, which archaeologists had argued are either frogs or toads. Bronze drums excavated in Wanjiaba do not carry such animals, but they frequently appear on Đông Sơn or Shizhaishan drums (Li Weiqing 1995). Figure 4 shows such animals on a Đông Sơn drum.

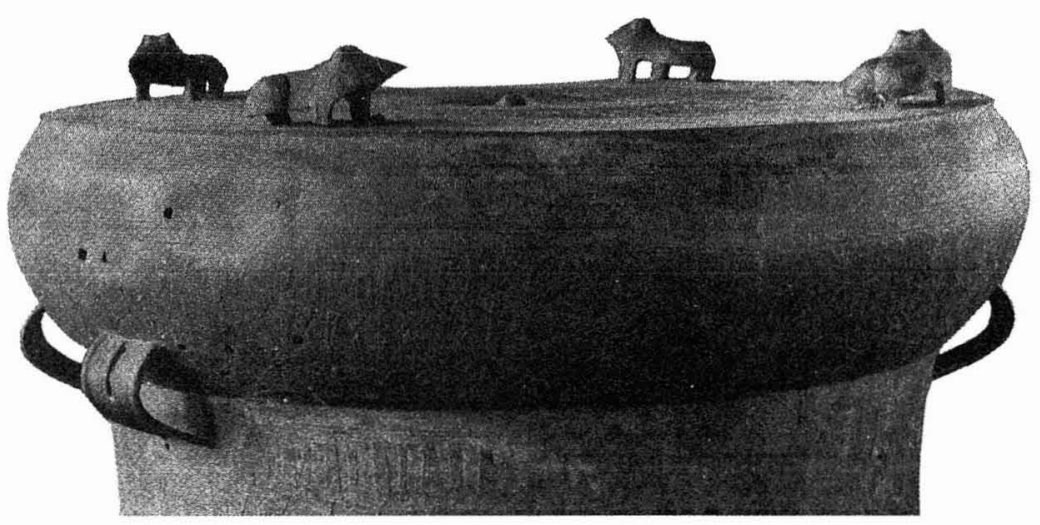

Fig. 4. Frogs or toads on a Đông Sơn drum (Phạm Huy Thòng 1990:154). 

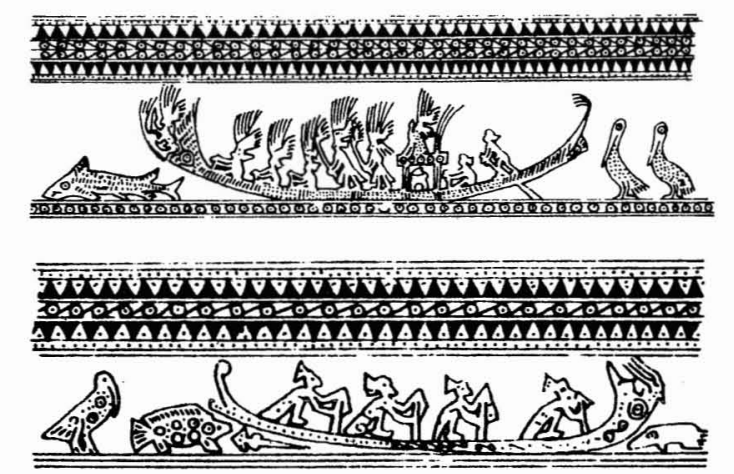

Fig. 5. Boats on bronze drums (Tong 1983:178).

Chinese scholars argued that these were frogs and explained them as either decorations devoid of any special meaning (Wen 1957) or something related to the ceremony of rain seeking, or the frog-worshiping custom of the ancient Yue people of southern China (ZGTY 1988:160-161). Edward Schafer (1967:254) agreed that the animals were frogs, "for the drum embodied a frog spirit - that is a spirit of water and rain - and its voice was the booming rumble of the bullfrog." He retold a story of the Tang period recorded in a Chinese source to show that the drum could even take the form of a living frog. According to the story, a frog pursued by a person leaped into a hole, which turned out to be the grave of a Man (southern barbarian) chieftain containing a bronze drum with a rich green patina, covered with batrachian figures. Thus, the bronze drum came to be perceived as the reincarnation of the frog (Schafer 1967:254). Some Vietnamese scholars agreed that the animals were frogs (Vũ Thế Long 1974:17), but others saw them as toads, because "a widely known popular saying in Vietnam calls the toad 'the uncle of the heavenly god' and maintains that rain will inevitably fall when the toad raises his head and croaks" (Phạm Huy Thòng 1990:268).

The motif of a long boat, illustrated in Figure 5, is another very popular decoration on the surface of the Đông Sơn (or Shizhaishan) drums. Usually, the two ends of the boat are decorated with the head and tail of a bird. In the boat are numerous ornamented human figures. There are fish under the boat and birds around the boat. Following the French scholar Goloubew, Đào Duy Anh believed this was a depiction of the "golden boat" described in the belief system of the Dayak people of Indonesia. The Dayaks believe that the "golden boat" carries the spirits of dead people to heaven. He further concluded that there was a possible blood relationship between the Dayaks and the Lạc Việt, and that the ancient Lạc Việt could be the ancestors of the Dayaks (Chen et al. 1988:335; cf. Matsumoto $1965: 136-142)$.

Feng Hanji, a Chinese archaeologist, did not agree. He believed the motif of the long boat was a reflection of the popular custom of boat racing in southern China. According to Feng, since the boat does not have an outrigger, it could only have been used in rivers or small inner waters like the Dian Lake. Moreover, decorating boats with birds was also an old Chinese tradition. He also believed that the motif might indicate some connections with the Chu (Feng 1974:5658). A similar argument was proposed by Ling Chunsheng as early as 1950 . Ling 

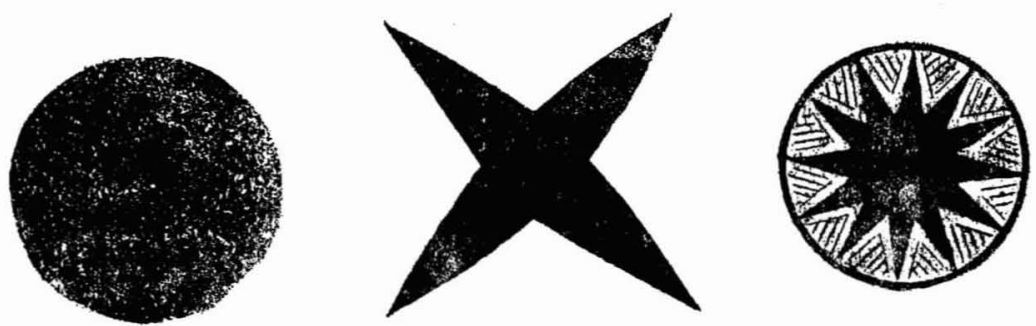

Fig. 6. Shining entities on bronze drums (ZGTY 1988:152).

argued that the motif of the long boat was a direct reflection of the custom of boat racing in ancient Chu. Although legend has it that boat racing was created to pay tribute to the memory of $\mathrm{Qu}$ Yuan, a Chu poet from the third century B.C., Ling argued that the custom had an earlier origin (Ling 1979 [1950]:542). Chinese scholars later noted that the boats on the bronze drums were of different kinds and were involved in different activities, all of which were popular in ancient southern China, namely, fishing, navigating, fighting, boat racing and offering sacrifices to the spirits of the river (Huang and Li 1986; ZGTY 1988:175181). Although Vietnamese scholars later accepted the idea that the motif was about boat racing, they persisted in their interpretation that what the boats depicted were part of the ancient Viet ceremony for seeking rain and water (Phạm Minh Huyền et al. $1987: 239$ ).

Figure 6 illustrates three different forms of a shining entity, which is typically located in the center of the surface of the bronze drum. Some scholars have interpreted this as a star, while others have viewed it to be the sun. It is not surprising to find that Vietnamese scholars believe that this reflects the ancient Viet custom of worshiping the sun (Đào 1974:30). Meanwhile, Chinese scholars have argued that many ancient ethnic groups in China, such as the Shang (or Yin), the $\mathrm{Chu}$, and other southern peoples, all worshipped the sun. Moreover, rulers tended to use the sun as a symbol of themselves (ZGTY 1988:151).

The two common geometric motifs on bronze drums as shown in Figure 7 are believed to represent clouds and thunder, respectively. According to Chinese scholars, the same motifs can be found on the ancient carved-motif pottery of southern China, as well as the bronze wares of the Central Plains and that, "[the motifs] prove the uniformity and continuity of the cultural development of ancient southern China and the frequent cultural exchange between southern China and the Central Plains" (ZGTY 1988:154). These motifs appear only occasionally on the Đông Sơn drums, but are frequently seen on Heger's Type II drums, most of which have been found in southern China, especially in Guangxi. While Vietnamese scholars did not openly express any objection to the Chinese claim that such motifs reflect Chinese influence, they strongly rejected the notion that such an influence proves that the bronze culture of the south developed under Chinese influence, and that drums bearing such motifs are the most ancient (Nguyễn Duy Hinh 1979:23).

In sum, Vietnamese scholars tend to view the decorations of early bronze drums, especially the Đông Sơn drum and its variants, as a reflection of the special cultural characteristics of the ancient Viet people. Armed with the belief that the 

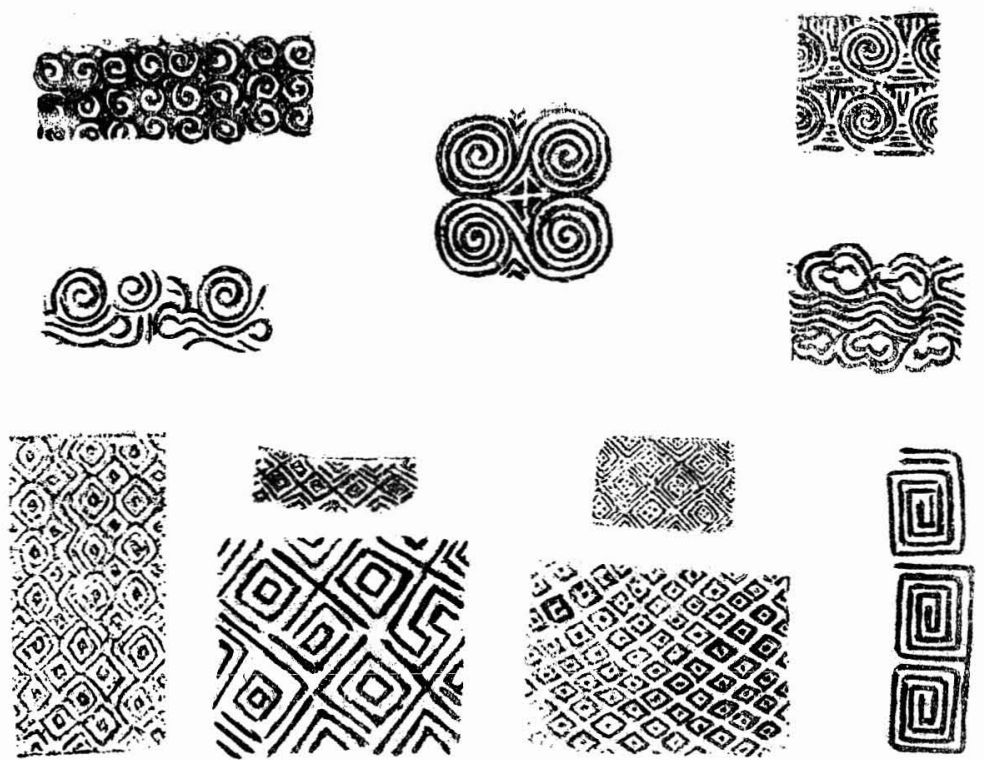

Fig. 7. Geometric designs representing clouds and thunder on bronze drums (ZGTY 1988:153).

various motifs on the bronze drum describe the life of the agrarian Viet culture of the Đông Sơn age (Đào 1974:28-29; Trần Quốc Vượng 1982:25), these scholars go on to argue that the decorations prove that the origins of the Đông Sơn drum lay with the ancient Viet people.

However, Chinese scholars interpreted the decorations as a reflection of the cultural exchange between interior China and China's frontier and the cultural features of the various peoples living in the south, including the Lạc Việt. Contrary to the Vietnamese view that the Đông Sơn culture and the bronze drum were invented in northern Viet Nam and later spread to southern China (Nguyễn Duy Hinh 1982a, 1982b; Phạm Huy Thòng 1982), Chinese scholars contended that the earliest drum was invented in a region belonging to modern China rather than Viet Nam: "the Đông Sơn drum is a developed form of the imported Chinese Shizhaishan drum, which spread from Yunnan to Viet Nam along the Red River" (ZGTY 1988:127-129). Citing both historical records and archaeological findings, Chinese scholars have tried to prove that the earliest drum was invented by the ancient Pu-Liao group on the eastern Yunnan plateau, and subsequently spread to its surrounding areas (He and Wu 1986; Hu 1986; Lin 1986; Tong 1990 [1983]: 181; Wang Ningsheng 1989 [1978] :305; ZGTY 1988:126-129). To support their theory that the Lạc Việt also belonged to this Pu-Liao group, Chinese scholars have cited similarities between the Dian culture of Yunnan and the Đông Sơn culture of Viet Nam as evidence (Liu 1995; Tong 1990 [1983]:174-175).

\section{NATIONALISM AND STUDIES OF THE BRONZE DRUM}

The functions, the molding methods, and other aspects of the bronze drum have also attracted much academic attention (Diệp 1974; Hoàng and Hà 1974; Jiang 
1982:38-52, 73-87, 1999; Phạm Minh Huyền et al. 1987:226-231, 240-243; Tong 1990 [1983]:177, 1987; Vũ Thế Long 1974; Wang Ningsheng 1989 [1978]:302-305, 1989; ZGTY 1988:138-148, 182-228). These issues, however, are less related to the origins of the bronze drum, and hence, differences on such issues have been more individual than national. Only in regard to issues that are more relevant to the ethnic and geographical origins of the bronze drum, such as its classification, dating, and the interpretation of the decorations, can a clear national difference be discerned. In fact, the issue of the origin of the bronze drum came to resemble a sacred topic in both countries. Yet, scholars in each country debated freely among themselves about minor issues. For example, there were Vietnamese scholars who supported the Chinese claim that the flying bird is an egret, and Chinese scholars who believed that the bird is the totem of the Lac people (Shi 1982:194). However, once the debate touched on the key issue of origin, all scholars took a nationalistic stand. Therefore, the Vietnamese scholars who supported the egret interpretation did not believe that a connection existed between the egret and the Chinese belief that the egret is the spirit of the drum, while Chinese scholars following the Lac bird explanation did not think it had any bearing on the Vietnamese origin of the bronze drum.

There was a clear national consensus among both Chinese and Vietnamese scholars pertaining to the origins of the bronze drum: there was not a single Vietnamese scholar who doubted the Vietnamese origin of the bronze drum. Likewise, there was not a single Chinese scholar who doubted the Chinese origin of the bronze drum. Such national consensus cannot be detected among Western or Japanese scholars who studied the bronze drum (Imamura 1973:37; Matsumoto 1965 : 131-147; Phạm Huy Thòng 1990:263-264; ZGTY 1988:10-11). The national consensus came about as part of the interplay between nationalist sentiment and the Communist political system in both countries: the former stimulated the archaeologists to make nationalistic claims, and the latter ensured that the nationalistic claims be made official views and dissident voices be suppressed. Similar national consensus had been achieved among archaeologists in wartime Japan on the official explanations of the origins of the imperial line, the Japanese state, and the Japanese people (Trigger 1989:179), in Nazi Germany concerning the ethnic and racial differences and the superiority of the German culture (Trigger 1989:163167), and in the Soviet Union in the 1930s and 1940s about the cultural achievements of the Slavic peoples (Shnirelman 1996:233-234).

Communist victory in China and Viet Nam brought about a process of historical reconstruction in both countries, guided by two important principles, Marxism and nationalism. The research of sensitive topics concerning the past relationship between the two countries, such as the issue of the origin of the bronze drum, was always permeated by a strong nationalistic spirit. When the two countries enjoyed good relations from the 1950s to the mid 1970s, that spirit was hidden with a Marxist internationalist coating. Hence, the Vietnamese and Chinese scholars made their own nationalistic claims while never openly accusing each other. For example, both Wen You and Đào Duy Anh published their works regarding bronze drums in the 1950s: Wen was the first Chinese scholar to attempt a modification of Heger's classification and propose a Chinese origin of the bronze drum, while Đào made the claim that the bronze drum was invented by 
the Lac Việt in northern Viet Nam and was then spread to other areas. Their works went unnoticed for about two decades. It was not until the late 1970s that the Chinese and Vietnamese scholars began to accuse each other of blending academic work with chauvinist or nationalistic agendas. The breakdown of SinoVietnamese bilateral relations in the late 1970 s brought nationalism to the forefront in both countries, thereby overriding the internationalism of the previous years.

For Vietnamese scholars, an essential part of reconstructing Vietnamese history was to prove the existence of the legendary Văn Lang state established by the Hung Kings, which was in turn part of a larger program to prove that the Red River delta was an early center of civilization independent of China. Archaeology played a very important role in reconstructing the early history of Viet Nam because of the lack of historical records. Glover rightly takes this as the reason why a country as poor as Viet Nam has devoted so much attention to archaeology.

The Vietnamese see in their Bronze Age, what they call the Dong Dau, Go Mun and Dong Son periods (from the late 2 nd to late 1st millennium B.C.) as the first flowering of native Vietnamese genius leading to the creation of a territorial political state or states with high levels of technical and artistic skills, before their subjection to Han Chinese imperialism at the start of the Christian era (Glover 1999:598).

The starting point of the Vietnamese scholars was to establish a direct relationship between the Hung Kings, the Lạc Việt, and the Đông Sơn culture, before proving that the Đông Sơn culture was indigenous to northern Viet Nam. To do so, they had to prove the native origin of the bronze drum, because it is the most important artifact of the Đông Sơn culture. According to Phạm Huy Thòng, who wrote the preface to the two special issues on bronze drums in the journal Khao Cổ Học,

In our process of studying the dawn of human history, namely, the age of the Hung Kings, the artifact that has gradually emerged as the most deserving symbol of the Hung Kings civilization is the bronze drum. More accurately speaking, it is the type I drum among the four types classified by Heger in the beginning of this century (Phạm 1974:9).

In his work on the bronze drum published posthumously in 1990, he declared,

the Đông Sơn drums were cast on Vietnamese soil by the bearers of the Đông Sơn culture at the time of state formation. They were the handiwork of the forebears of the present-day Vietnamese, the ancient Viet state builders who were conscious of their ethnic and cultural identity (Phạm 1990:262).

According to Pham, the idea that the bronze drum was an original and typical artifact of the Đông Sơn culture was first brought up in the four-volume collective historical work Hùng Vuong Dưng Nươ (The Founding of the State by the Hung Kings), published between 1969 and 1971, and that, since then, it had become the foundation on which all further studies of the Đông Sơn culture were based (Phạm 1990:264). Between 1968 and 1971, four symposia were held to discuss the ancient history of Viet Nam, and scholars from around the country had come to the consensus that the era of the Hung Kings could be linked to the bronze age archaeological artifacts discovered in northern Viet Nam, which were taken as the material evidence of the existence of the Hung Kings. It was suggested that spe- 
cial attention should be paid to the links between the legends about the Hung Kings and the bronze drums (Nguyễn and Hoàng 1975 :132). A book about how the Hung Kings built the Vietnamese nation published in the 1980s has a picture of a bronze drum on its cover, and lists the bronze drum as the most typical artifact of the Đông Sơn culture (Sở Văn Hóa-Thông Tin Vĩnh Phú 1985). In summary, the bronze drum is deemed important in the construction of the Vietnamese national identity because it is believed to form an important link in the evolution of the indigenous civilization.

For Chinese archaeologists, bronze drums served different purposes at different times. For the older generation of Chinese scholars like Luo Xianglin and Xu Songshi, the various ethnic groups in southern China were all branches of the larger Han Chinese race. They supported Sun Yat-sen's claim that China had only five ethnic groups, namely, Han, Hui (Muslims), Manchus, Mongols, and Tibetans. This classification included most ethnic minorities in southern China in the Han group (Luo Xianglin 1943:1-2; Xu Songshi 1977:96-97). Since both Luo and $\mathrm{Xu}$ were southerners themselves, it was unsurprising to find that they viewed the bronze drum as an indicator of the cultural achievement of the southern Chinese as well as a symbol of southern identity.

After 1949, the Chinese government officially identified many southern groups as ethnic minorities independent of the Han, and the official views hold that the minority peoples have their own cultural achievements, that historically there has been much mutual influence between Han Chinese and the southern minorities, and that the minority groups have all contributed to a common Chinese civilization. Chinese archaeologists who study the bronze culture of southern China tend to emphasize the influence of Han Chinese culture (cf. Feng 1974; Wang 1989 [1980]), while regarding at the same time the southern bronze culture as evidence for the ingenuity of the minority groups. As a result, the bronze drum, which was sometimes scorned by traditional Chinese scholars because of its "barbarian" origins, ${ }^{2}$ is now regarded as one of the most magnificent material relics of the southern minority peoples and the symbol of interior-frontier cultural exchange. Wen You wrote, "If someone asks, what is the most important ancient cultural relic of our minority siblings in southern China, we can answer him unhesitatingly that it is the bronze drum." The bronze drum, he further claimed, is the "common treasure of all the people of China" (Wen 1957, preface). The authors of an article about the ethnic affiliations of the various types of bronze drum concluded that their study,

reflects in a specific aspect the process of ethnic mixture and cultural exchange among the brotherly ethnic groups of China, [and] sufficiently proves that the various ethnic groups in southern China, together with other ethnic groups of China, created the great, brilliant ancient culture of the Chinese nation ( $\mathrm{Li}$ and $\mathrm{Xi}$ 1983:427).

Since the reunification of Viet Nam, Vietnamese scholars have adopted a similar attitude in their study of the Indianized Cham civilization by valuing it as a glorification of a greater Vietnamese tradition (Glover 1999:598).

As in the pre-1949 period, research on the bronze drum in China after 1949 might still be related to the construction of local identities, and the expressions of local pride, as is evident in the subtle differences between some Guangxi and Yunnan scholars on the issue of the origins of the bronze drum. Such local senti- 
ment has become part of a regionalist paradigm since the late 1970s (cf. Falkenhausen 1995).

The research methods of the Vietnamese and Chinese archaeologists are quite similar to each other. Roughly speaking, scholars in both countries followed the methods of the culture-history school. Their research usually consisted of three stages. The first stage was to identify the earliest bronze drum and by so doing establishing links between the earliest bronze drum and a place-usually it is the place where it was excavated, be it Đông Sơn in Viet Nam or Guangxi or Wanjiaba (Yunnan) in China. The second stage was to establish links between the earliest bronze drum and an ancient ethnic group by identifying some racial or cultural markers discovered from the bronze drum. The most important racial markers are the decorations of the bronze drum, including the flying bird, long boat, shining entity, and others. Their final stage of research was to prove the connections between the ancient ethnic group they identified and certain living human groups, thus Vietnamese scholars claim the Lạc Việt as the direct ancestors of the Vietnamese, whereas Chinese scholars believe that the $\mathrm{Pu}$-liao group was the common ancestor of certain ethnic groups in present-day southern China and Southeast Asia. Scholars from both countries made extensive use of historical records, and they all endeavored to match archaeological materials with ethnic groups described in official and unofficial annals and gazetteers.

The researchers came across serious difficulties and sometimes had to base their conclusions on assumptions in each of the three stages. In the first stage, dating the bronze drum was not an easy task and archaeologists in the two countries conceptualized totally different relative and absolute dates. Moreover, scholars in both countries had to assume that the bronze drums discovered on their own soil had been made in the local area. In the second stage, the interpretation of the decorations and identification of racial markers can be very arbitrary and subjective. As a result, the same set of motifs were sometimes interpreted as racial markers of different ethnic groups by scholars from the two countries. In the third stage, archaeologists from both countries were all primordialists who presupposed that ethnic or national identity already existed at the time the bronze drum was invented, and that this ethnic or national identity underwent no dramatic changes between then and now.

The culture-history approach is the favorite method of nationalist archaeologists around the world (Bailey 1998:97; Kaiser 1995; Kohl and Fawcett 1995:14; Kotsakis 1998:56-57; Trigger 1989:174-186). In East Asia, Chinese and Vietnamese archaeologists are not the only nationalistic culture-historians. Korean and Japanese archaeologists have adopted the same method in the reconstruction of their national history and national identity, and they have made similar assumptions about racial or cultural markers and the continuity of ethnic or national identity (Hudson 1999:1-55; Nelson 1995; Pai 2000:1-27). The Vietnamese archaeological project of linking the legend of the Hung Kings and the kingdom of Văn Lang to archaeological materials is mirrored by the effort of Korean archaeologists at proving the existence of the legendary Tangun and the kingdom of Kochoson with archaeological evidence.

The core issue in the Sino-Vietnamese debate is that both Vietnamese and Chinese scholars try to make exclusive claims on an invention that was possibly shared by the various groups which inhabited ancient southern China and South- 
east Asia. There was no political or cultural boundary between southern China and northern Viet Nam at the time the bronze drum was invented. The ancient groups living in this vast area were interrelated either physically, culturally, or both. The people who invented the bronze drum would have had no consciousness of polities such as "Viet Nam" or "China," as we do today. It is therefore unfair to impose such modern concepts on ancient peoples and to determine exactly when and where the bronze drum was invented and who invented it. Charles Higham, an outsider to these disputes, commented that the nationalistic bias of the Vietnamese and Chinese archaeologists had obscured the situation revealed by archaeology. He hypothesized that the bronze drum was created by the specialized artisans of a cluster of increasingly complex polities that spread across the present-day Sino-Vietnamese border to arm the warriors of their polities and signal the high status of their leaders. He concludes, "Seeking the origins of this trend and the associated changes in material culture in one or other particular region misses the point. Changes were taking place across much of what is now southern China and the lower Red River Valley by groups which were exchanging goods and ideas, and responding to the expansion from the north of an aggressive, powerful state" (Higham 1996:134). In fact, the theme surrounding the bronze drum could equally make for an excellent story about cultural coprosperity and unity of the various peoples living in this area. Several scholars have pointed out the similarities between the Đông Sơn culture of northern Viet Nam and the Dian culture of Yunnan, China, but have refrained from stating which was earlier or later (Chang 1977:466-467; Solheim 1990; Tessitore 1990). The Japanese archaeologist Yoshikai Masato has tried to adopt a new approach in bronze drum studies by disregarding the modern national boundary between China and Viet Nam (Yoshikai 1998). Several other recent studies have also taken southern China and northern Viet Nam as one cultural area, without attempting to link their archaeological cultures to any ancient ethnic groups, or to locate the invention of a particular archaeological culture on this or that side of the modern political boundary (cf. Nitta 1986; Trình Năng Chung 1997, 1999).

It is interesting to note that in order to prove the indigenous origins of the bronze drum (in either southern China or northern Viet Nam); both Vietnamese and Chinese scholars have vehemently denied any possibility of a place of origin outside of the present-day southern China and northern Viet Nam landmass. The theory about the Indian origin of the bronze drum and the theories about the Cambodian and European origins of the Dong Son culture have all been criticized by both Vietnamese and Chinese scholars (ZGTY 1988:10-11). In fact, this is ironically the only significant common ground for scholars from the two countries about the origin of the bronze drum.

The obscurity of the information about the bronze drum is an important factor in the whole debate. There are no inscriptions on the early bronze drums. The records in Chinese classics about the origins of the bronze drum are often contradictory and fragmentary. Modern techniques have also failed to provide hard evidence. Moreover, neither Chinese nor Vietnamese archaeologists were able to examine the bronze drums excavated and stored by their opponents. There was no normal academic exchange between the two countries during that period. In a diary entry written in December 1986, the Chinese archaeologist Wang Ningsheng stated frankly, 
Bronze drum studies have become a craze in recent years. There is not much new information, but there are quite many publications and grand theories. There are opposing views. On the issue of classification alone more than ten schemes have been proposed. I no longer have much interest in the topic (Wang 1997:274).

The lack and obscurity of information makes the bronze drum an artifact ambiguous enough for both sides to inject some meaningful interpretation into it for themselves, resulting in neither side being able to persuade the other. It is this same ambiguity that makes it difficult for an outsider to determine which side is right or wrong.

Largely as a result of improved Sino-Vietnamese bilateral relations, the crossfire between Chinese and Vietnamese scholars over issues surrounding bronze drums has come to an end. In spite of this, neither side has changed its stance. They have merely set the issue aside, or have made their own claims from time to time without openly accusing the opposite side, a situation similar to that which prevailed in the 1950 s and 1960s. Hence, the issue has been suppressed but not resolved, and it will probably re-emerge under new circumstances. There have been frequent academic exchanges between Chinese and Vietnamese scholars since the early 1990s (Jiang 1999:280-281), and scholars have turned their attention from the origins to other aspects of the bronze drum. However, the views on the origins of the bronze drum held by each side are not likely to change in the near future, as it is the result of a tradition that has existed in the two countries for a long time-a tradition of making official history and of using the past to serve the present.

\section{ACKNOWLEDGMENTS}

The author wishes to thank Miriam Stark, Bruce Lockhart, and two anonymous reviewers for Asian Perspectives for their helpful comments and suggestions. Thanks also goes to Liam Kelley for editorial assistance in preparing an earlier version of this article. The author alone bears responsibility for all errors.

\section{NOTES}

1. Fan Chengda, a scholar-official of the Song dynasty (A.D. 960-1279), first suggested that the bronze drum was invented by Ma Yuan. A scholar in the Ming dynasty (1368-1644) first recorded that the big bronze drum was invented by Ma Yuan, and the small one by Zhuge Liang. F. Hirth tried to prove these stories in two articles published in 1898 and 1904 (Zheng Shixu 1936, 3-5, 14, 33-37). Today, however, no one follows these ideas.

2. For example, Wen You lamented that traditional Chinese scholars before the Qing dynasty seldom paid serious attention to the bronze drum because it did not have inscriptions and that it was made by the "barbarians." During the Qing dynasty, however, more attention was paid to the bronze drum and several books were produced. Wen attributed this to the myth about Ma Yuan and Zhuge Liang creating the bronze drum that gradually became popular in China after the Song dynasty (Wen 1957, preface).

\section{REFERENCES CITED}

Arnold, B., And H. Hassmann

1995 Archaeology in Nazi Germany: The legacy of the Faustian bargain, in Nationalism, Politics, and the Practice of Archaeology: 70-81, ed. P. L. Kohl and C. Fawcett. Cambridge: Cambridge University Press. 
BAILEY, D. W.

1998 Bulgarian archaeology: Ideology, sociopolitics and the exotic, in Archaeology Under Fire: Nationalism, Politics and Heritage in the Eastern Mediterranean and Middle East: 87-110, ed. L. Meskell. London: Routledge.

Chang, Kwang-CHIH

1977 Archaeology of Ancient China. 3rd edition. New Haven: Yale University Press.

Chen Guoqiang, Jiang Binzhao, Wu Mianqi, and Xing Tucheng

1988 Baiyue minzu shi [A History of the Yue Groups]. Beijing: Zhongguo shehui kexue.

CHư VĂN TẦN

1974 Niên đại Trống Đông Sơn [The dating of the Dong Son drum]. Khảo Cổ Học 13:106116.

1982 Phải chăng họ dã tìm thấy trống X? [Have they really discovered drum X?]. Khảo Cổ Học $9: 29-37$.

ĐÀO Tử KHẢI

1974 Chim Lạc hay con cò? Ngôi sao hay mặt trời? [Lạc bird or egret? Star or sun?). Khảo Cổ Hoc $14: 27-31$.

Diaz-Andreu, M., and T. Champion, eds.

1996 Nationalism and Archaeology in Europe. Boulder, Colorado: Westview Press.

DiệP ĐINH HOA

1974 Công Dụng của Trống Đồng Cổ [Functions of the ancient bronze drum]. Khảo Cổ Học $14: 44-53$.

DiệP Đinh HoA, AND Phạm Minh Hữ̂̀n

1974 Về việc chia loại trống loại I Hê-gơ và mối quan hệ giữa loại trống này với các loại trống khác [The classification of Heger's Type I bronze drums and its relationship with other types of bronze drum]. Khảo Cổ Học 13:126-134.

ĐiNH BÁ HOÀ

1998 Những Trống Đồng Đông Sơn được phát hiện tại Bình Định [Dongson drums found in Binh Dinh]. Khảo Cổ Học 4 : 52-65.

FALKenhausen, L. V.

1995 The regionalist paradigm in Chinese archaeology, in Nationalism, Politics, and the Practice of Archaeology: 198-217, ed. P. L. Kohl and C. Fawcett. Cambridge: Cambridge University Press.

FENG HANJI

1974 Yunnan Jinning chutu tonggu yanjiu [A study of the bronze drums of Jinning, Yunnan]. Wen $W_{u} 1: 51-61$.

GLOVER, I.

1999 Letting the past serve the present - some contemporary uses of archaeology in Vietnam. Antiquity 73:594-602.

He Jiejun, And Wu Mingsheng

1986 Zhizao he shiyong tonggu shi puxi minzu gudai wenhua de tezheng [Making and using bronze drum is a cultural feature of the ancient $\mathrm{Pu}$ groups], in Zhongguo tonggu yanjiuhui di'erci xueshu taolunhui lunwenji [Proceedings of the Second Symposium of the Chinese Association for Bronze Drum Studies]: 152-160. Beijing: Wenwu.

Heger, F.

1902 Alte Metalltrommeln aus Südostasien. Leipzig: K. W. Hiersemann.

Higham, C.

1996 The Bronze Age of Southeast Asia. Cambridge: Cambridge University Press.

Hirth, F.

1891 Alte bronzepauken aus Ostasien. Vienna.

HOÀng VĂN KHOÁN, AND HÁ VĂN TẤN

1974 Tìm Hiểu Kỹ Thuật Đúc Trống Đồng Ngọc Lụ̃ [Understanding the molding method of the Ngoc Lu drum]. Khảo Cổ Học 14:37-43.

Hong SHeng

1974 Guangxi gudai tonggu yanjiu [A study of the ancient bronze drums of Guangxi]. Kaogu Xuebao $1: 45-90$. 


\section{HU ZHENDONG}

1986 Yunnan xing tonggu de chuanbo yu puren de bianqian [The spread of the Yunnan style bronze drum and the transformation of the $\mathrm{Pu}$ group]. In Zhongguo tonggu yanjiuhui di'erci xueshu taolunhui lunwenji [Proceedings of the Second Symposium of the Chinese Association for Bronze Drum Studies]: 142-151. Beijing: Wenwu.

Huang Derong, and Li Kunsheng

1986 Tonggu chuanwen kao [The motifs of boat on the bronze drum], in Zhongguo tonggu yanjiuhui di'erci xueshu taolunhui lunwenji [Proceedings of the Second Symposium of the Chinese Association for Bronze Drum Studies]: 249-261. Beijing: Wenwu.

HuANG ZengQING

1964 Guangxi tonggu chutan [A preliminary study of the bronze drums of Guangxi]. Kaogu $11: 578-588$

HudSON, MARK J.

1999 Ruins of Identity: Ethnogenesis in the Japanese Islands. Honolulu: University of Hawai' $\mathrm{i}$ Press.

IMAMURA KeIJI

1973 Koshiki dôko no hensen to kigen [The transformation and origin of the ancient bronze drum]. Kokogaku zashi 59(3):35-62.

JIANG TINGYU

1982 Tonggu shihua [History of the Bronze Drum]. Beijing: Wenwu.

1999 Gudai Tonggu tonglun [A General Survey of the Ancient Bronze Drums]. Beijing: Zijincheng.

KAISER, T

1995 Archaeology and ideology in southeast Europe, in Nationalism, Politics, and the Practice of Archaeology: 99-119, ed. P. L. Kohl and C. Fawcett. Cambridge: Cambridge University Press.

KarLgren, B.

1942 The date of the early Dong-son culture. Bulletin of the Museum of Far Eastern Antiquities $14: 1-28$.

Kohl, P. L., AND C. FAwCetT

1995 Archaeology in the service of the state: Theoretical considerations, in Nationalism, Politics, and the Practice of Archaeology: 3-18, ed. P. L. Kohl and C. Fawcett. Cambridge: Cambridge University Press.

Kohl, P. L., And C. Fawcett, eds.

1995 Nationalism, Politics, and the Practice of Archaeology. Cambridge: Cambridge University Press.

KoTSAKIS, K.

1998 The past is ours: Images of Greek Macedonia, in Archaeology Under Fire: Nationalism, Politics and Heritage in the Eastern Mediterranean and Middle East: 44-67, ed. L. Meskell. London: Routledge.

Li Kunsheng, and Huang Derong

1991a Lun Yunnan zaoqi tonggu [On the early bronze drum of Yunnan]. Kunming shifan xueyuan xuebao, 1980(4), in Yunnan qingtong wenhua lunji [Collected Essays on the Bronze Culture of Yunnan]: 366-373, ed. Yunnan sheng bowuguan. Kunming: Yunnan renmin.

$1991 b$ Zailun Yunnan zaoqi tonggu [More on the early bronze drums of Yunnan]. Kaogu 1990(5), in Yunnan qingtong wenhua lunji [Collected Essays on the Bronze Culture of Yunnan]: 374-393, ed. Yunnan sheng bowuguan. Kunming: Yunnan renmin.

LI WEIQING

1979 Zhongguo nanfang tonggu de fenlei he duandai [The classification and dating of the bronze drums of southern China]. Kaogu 1:66-78.

1991 Guanyu tonggu qiyuan de ruogan wenti [Some issues about the origin of the bronze drum], in Yunnan qingtong wenhwa lunji [Collected Essays on the Bronze Culture of Yunnan]: 476-495, ed. Yunnan sheng bowuguan. Kunming: Yunnan renmin.

1995 Tonggu liti shiwu yanjiu [A study of the three-dimensional decorations of the bronze drum]. Yunnan minzu xueyuan xuebao 1:34-41.

Li Weiqing, AND Xi Keding

1983 Shi tan zhong guo nan fang tong gu de $\mathrm{zu}$ shu [An inquiry into the ethnic affiliations of the bronze drums of southern China], in Xi nan min zu yan jiu [Studies on the Ethnic Groups of Southwestern China]: 413-428. Chengdu: Sichuan Minzu Press. 
LIN BANGEUN

1986 Shilun Puren xianmin de tugu jiqi yu nanfang tonggu de guanxi [On the relations between the earthern drum made by the ancestors of the Pu people and the bronze drum of southern China, in Zhongguo tonggu yanjiuhui di'erci xueshu taolunhui lunvenji [Proceedings of the Second Symposium of the Chinese Association for Bronze Drum Studies]: 132-141. Beijing: Wenwu.

LING SHUN-SHENG

1979 [1950] Ji benxiao er tonggu jianlun tonggu de qiyuan he fenbu [Notes on the collection of two bronze drums from National Taiwan University with the discussion of their origin and distribution]. Guoli Taiwan daxue xuebao 1, in Zhongguo bianjiang minzu yu huan taipingyang wenhua [Studies of Chinese Minorities and Circum-Pacific Culture], vol. 1:503-556, ed. Ling Shun-sheng. Taipei: Lianjing.

LIU YAN

1995 Pu Shuo santi [On three issues about the Pu]. Yunnan minzu xueyuan xuebao 3:20-26.

LOOFS-Wissowa, H.H.E.

1983 The development and spread of metallurgy in Southeast Asia: A review of the present evidence. Journal of Southeast Asian Studies 14(1):1-11.

\section{Luo Xianglin}

1943 Zhongxia xitong zhi Baiyue [The Yue Groups as a Branch of the Chinese Race]. Chongqing: Duli Press.

LưU TrẦn TiÊU, AND NGUYẼ̃N MINH CHƯơng

1974 Niên đại trống Đông Sơn [The dating of the Dong Son drums]. Khảo Cổ Học 13:117121.

Matsumoto, N.

1965 Kodai Indoshina tôsakumin shûkyô shisô no kenkŷ̉—Ko dôko no monyô wo tsûjite mitaru [A Study of the Religious Thought of the Rice Cultivators in Ancient Southeast Asia: Based on the Decorations of the Ancient Bronze Drum]. Tokyo: The Japanese Society of Ethnology.

Meskell, L., ED.

1998 Archaeology Under Fire: Nationalism, Politics and Heritage in the Eastern Mediterranean and Middle East. London: Routledge.

Meyer, A. B., AND W. Foy

1897 Bronzepauken aus Südostasien. Dresden.

NeLSON, S. M.

1995 The politics of ethnicity in prehistoric Korea, in Nationalism, Politics, and the Practice of Archaeology: 218-231, ed. P. L. Kohl and C. Fawcett. Cambridge: Cambridge University Press.

NGUYỄN DUY HINH

1974 Trống đồng trong sử sách [The bronze drums in historical records]. Khảo Cổ Học 13:1835.

1979 Về quan điểm của một số học giả Trung Quốc nghiên cứu Trống đồng người Việt [A review of the views of some Chinese scholars on the bronze drums of the Vietnamese people]. Khảo Cổ Học 4:17-26.

$1982 a$ Đồ đồng vùng Tây Nam Trung Quốc [Bronze articles in southwest China]. Khảo Cổ Học $1: 61-66$.

$1982 b$ Đồ đồng vùng Đông Nam Trung Quốc [Bronze articles in southwest China]. Khảo Cổ Hoc 2:29-33.

1987 Bronze drums in Vietnam. The Vietnam Forum 9:1-22.

NGUYỄN VĂN HUYÊN

1974 Từ chia loại, chia nhóm đến tìm hiều niên đại và quê hứ̛ng của trống đồng [From the classification and subclassification of the bronze drums to the understanding of their dating and origins]. Khảo Cổ Học 13:95-105.

NGUYỄN VĂN HUYÊN, AND HoÀNG VINH

1975 Nhüng trống đồng Đông Sơn đã phát hiện ở Việt Nam [The Dong Son bronze drums discovered in Vietnam]. Hanoi: Viện Bảo Tàng Lịch Sử Việt Nam.

NitTa Eiji

1986 Buronzu Toraianguru: Seiritsu to tenkai [Bronze triangle: Its origin and development]. Kagoshima University Historical Science Reports 33:17-40. 
PAI Hyung II

2000 Constructing "Korean" Origins: A Critical Review of Archaeology, Historiography, and Racial Myth in Korean State-Formation Theories. Cambridge: Harvard University Press.

Peng Nanlin

1991 "Xian Heige'er yishi tonggu" shuo [The concept of pre-Heger Type I bronze drums], in Yunnan qingtong wenhua lunii [Collected Essays on the Bronze Culture of Yunnan]: 394-410, ed. Yunnansheng Bowuguan. Kunming: Yunnan renmin.

PHẠM Dúc MạnH

1997 Trống Đồng Phú Chánh [Phu Chanh bronze drums]. Khảo Cổ Học 3:45-54.

PHẠM HuY THÒNG

1974 Trống Đồng [The bronze drum]. Khảo Cổ Học 13:9-11.

1982 Văn hóa Đông Sơn trên lãnh thổ Trung Quốc ngày nay? [Dong Son culture on present Chinese territory?]. Khảo Cổ Học 1:57-60.

1990 Dong Son Drums in Vietnam. Hanoi: The Vietnam Social Science Publishing House.

Pham Minh Huyền, NguyẼ̃n VĂN Huyên, And Trinh Sinh

1987 Trống Đông Sơn [The Dong Son Drums]. Hanoi: Nhà Xuầt Bản Khoa Học Xã Hội.

QIU ZhongLUN

1982 Ma Yuan huo Luoyue tonggu didian kao [The place where Ma Yuan collected bronze drums from the Luoyue people], in Zhongguo tonggu yanjiuhui di'erci xueshu taolunhui lunwenji [Proceedings of the Second Symposium of the Chinese Association for Bronze Drum Studies]: 159-162. Beijing: Wenwu.

SCHAFER, E.

1967 The Vermilion Bird. Berkeley: University of California Press.

SHI ZHONGJIAN

1982 Shizheng Yue yu Luoyue chuzi tongyuan [On the common origin of the Yue and Luoyue (Lac Việt)], in Baiyue minzushi lunji [Essays on the History of the Yue Groups]: 183204, ed. Baiyue minzushi yanjiuhui. Beijing: Zhongguo shehui kexue.

1983 Ancient bronze drums. China Pictorial 10:25-26.

Shnirelman, V. A.

1996 Faces of nationalist archaeology in Russia, in Nationalism and Archaeology in Europe: 218242, ed. M. Diaz-Andreu and T. Champion. Boulder, Colorado: Westview Press.

Silberman, N. A.

1989 Between Past and Present: Archaeology, Ideology, and Nationalism in the Modern Middle East. New York: Henry Holt and Company.

Sở Văn Hóa-Thông TIN VĨNh Phú

1985 Các Vua Húng pãa có công dưng nước ... . Tập luận văn kỷ niệm 30 năm ngày Bác Hồ đến tham Đền Hùng: 19-9-1954-19-9-1984 [The Hung Kings Have Contributed to Building Our Nation]. Vĩnh Phú.

Solheim, W. G., II

1990 A brief history of the Dongson concept. Asian Perspectives 28:23-30.

SPENNEMANN, D.H.R.

1987 Evolution of Southeast Asian kettle-drums. Antiquity 61:71-75.

Tessitore, J.

1990 View from the east mountain: An examination of the relationship between the Dong Son and Lake Tien civilizations in the first millennium B.C. Asian Perspectives $28: 31-44$.

TONG ENZHENG

1990 [1983] Shilun zaoqi tonggu [On the early bronze drums]. Kaogu Xuebao 3, in Zhongguo xinan minzu kaogu lunwenji [Collected Essays on the Ethnoarchaeology of Southwestern China]: 163-185. Beijing: Wenwu.

1990 [1986] Zailun zaoqi tonggu [More on the early bronze drums], in Zhongguo tonggu xuehui dierci xueshu taolunhui lunwenji [Proceedings of the Second Symposium of the Chinese Association of Bronze Drum Studies]. Beijing: Wenwu; and in Zhongguo xinan minzu kaogu lunwenji [Collected Essays on the Ethnoarchaeology of Southwestern China]: 186-199, ed. Zhongguo tonggu yanjiuhui. Beijing: Wenwu.

1995 Thirty years of Chinese archaeology (1949-1979), in Nationalism, Politics, and the Practice of Archaeology: 177-197, ed. P. L. Kohl and C. Fawcett. Cambridge: Cambridge University Press. 
Trần Mạnh PHú

1974 Thử chia nhóm những trống dồng loại I Hê-gơ phát hiện ở Việt Nam [The classification of Heger's Type I bronze drums discovered in Vietnam]. Khảo Cố Học 13:83-94.

TRẦn Quốc VượnG

1982 Mấy ý kiến về trống đồng và tâm thức Việt cổ [Some comments on the bronze drum and the mentality of the ancient Viet people]. Khảo Cổ Học 3:17-25.

Trigger, B. G.

1984 Alternative archaeologies: Nationalist, colonialist, imperialist. Man 19:355-370.

1989 A History of Archaeological Thought. Cambridge: Cambridge University Press.

\section{TRÍNH NĂNG CHUNG}

1997 Văn hóa xẻng đá lớn ở Quảng Tây, Trung Quốc vá mối quan hệ với Bắc Việt Nam [The Big Stone Shovel culture in Guangxi, China and its relationship to northern Viet Nam]. Khảo Cổ Hoc 2: 85-92.

1999 Giai đoạn hậu kỳ đá mới ờ Văn Nam Trung Quốc vá mối quan hệ vọ́i Bắc Việt Nam [The Late Neolithic period in Yunnan of China and its relationship to northern Viet Nam]. Khảo Cổ Học 1:80-91.

Vũ Ngọc Thư

1974 Suy nghĩ về cách đúc trống đồng [About the method of molding the Bronze drum]. Khảo Cổ Họ 14:32-36.

VŨ THẮNG

1974 Tình hình phân bố trống Đông Sơn Ở Việt Nam Và Đông Nam Á [The distribution of the Dong Son drum in Viet Nam and Southeast Asia]. Khảo Cổ Học 13:9-17.

VŨ THẾ LONG

1974 Hính vá tượng động vật trên trống vá các đồ đồng Đông Sơn [The motifs and figurines of animals on drums and other Dongsonian bronze artifacts]. Khảo Cổ Học 14:9-17.

WANG Dadao

1990 Yunnan qingtong wenhua jiqi yu Yuenan Dongshan wenhua, Taiguo Banqing wenhua de guanxi [The Bronze culture of Yunnan and its relations with the Dong Son culture of Viet Nam and the Ban Chiang culture of Thailand]. Kaogu 6:531-543.

WANG NINGSHENG

1989 Shilun zhongguo gudai tonggu [On the ancient bronze drums of China]. Кaogu Хue[1978] bao 2, in Minzu kaoguxue lunji [Collected Essays on Ethnoarchaeology]: 277-306. Beijing: Wenwu.

1989 Shilun Shizhaishan wenhua [On the Shizhaishan culture], in Zhongguo kaogu xuehui [1980] diyici nianhui lunwenji [Proceedings of the First Annual Conference of the Chinese Archaeological Association], ed. Zhongguo kaogu Xuehui. Beijing: Wenwu. Reprinted in Wang Ningsheng, Minzu kaoguxue lunji [Collected Essays on Ethnoarchaeology]: 322-342. Beijing: Wenwu.

1989 Tonggu yu nanfang minzu [The bronze drum and the ethnic groups in southern China]. Changchun: Jilin jiaoyu.

1997 Xinan Fanggu Sanshiwu Nian [MY Thirty-five Years of Archaeological Fieldwork in Southwestern China]. Jinan: Shandong huabao.

Wen You

1957 Gu tonggu tulu [Collected Pictures of the Ancient Bronze Drums]. Beijing: Zhongguo gudian yishu.

Wenwи Bianji Weiyuanhui (Editorial Board of Wenwu)

1990 Wenuru kaogu gongzuo shinian: 1979-1989 (A Decade of Work in the Field of Cultural Relics and Archacology: 1979-1989). Beijing: Wenwu.

WIWJORRA, I.

1996 German archaeology and its relation to nationalism and racism, in Nationalism and Archaeology in Europe: 164-188, ed. M. Diaz-Andreu and T. Champion. Boulder, Colorado: Westview Press.

Xinhua News Agency

1995 Nanfang tonggu wenhua yanjiu you chengguo [New Results Attained in the Study of the Bronze Drum Culture of Southern China]. January 12.

Xu SONGSHi

1977 Baiyue xiongfeng lingnan tonggu [The Masculine Spirit of the Yue Groups and the Bronze Drums 
of Southern China]. Asian Folklore and Social Life Monographs 95. Taibei: The Orient Cultural Service.

YI XUEZHONG

1987 Tonggu gumian "sifeiniao" tuxiang xinjie [A new interpretation of the "four flying birds" on the bronze drum]. Kaogu 6:551-554.

Yoshikai Masato

1998 Dôko saihen no jidai: daiichi sennenki no Betonamu to Chûgoku [Reorganization of bronze drum traditions in Viet Nam and South China during the first millenium A.D.]. Tồố bunka 78:199-218.

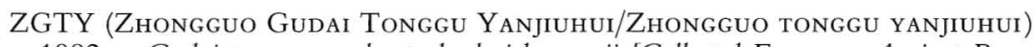

1982 Gudai tonggu xueshu taolunhui lunwenji [Collected Essays on Ancient Bronze Drums]. Beijing: Wenwu.

1986 Zhongguo tonggu yanjiuhui di'erci xueshu taolunhui lunwenji [Proceedings of the Second Symposium of the Chinese Association for Bronze Drum Studies]. Beijing: Wenwu.

1988 Zhongguo gudai tonggu [The Ancient Bronze Drums of China]. Beijing: Wenwu.

ZHANG SHIQUAN

1982 Lun gudai tonggu de fenshi [On the classification of ancient bronze drums], in Gudai tonggu xueshu taolunhui lunwenji [Collected Essays on Ancient Bronze Drums]: 95-107. Beijing: Wenwu.

ZHENG SHIXu

1936 Tonggu kaolüe [A Study of the Bronze Drum]. Shanghai: Shanghai Museum.

\begin{abstract}
This paper reviews the Sino-Vietnamese archaeological debate of the 1970s and 1980s pertaining to the origins of the bronze drum, specifically analyzing how nationalism and international politics had an impact on both the questions posed by archaeologists as well as the answers they provided to these questions. Based on a reading of the major works on the bronze drum published in Viet Nam and China since the 1950s, particularly those published in the 1970s and 1980s, this paper argues that the debate between Chinese and Vietnamese archaeologists on the origins of the bronze drum in general, and the dating, classification, and interpretations of the decorations of the bronze drum in particular, had many of its origins in the political and military conflicts between the two countries, to the extent that an individual archaeologist's views of certain issues were largely determined by his nationality. KeYwords: archaeology, bronze drum, China, nationalism, Viet Nam.
\end{abstract}

